ТЕХНОЛОГІЯ ФОРМУВАННЯ ПРОФЕСІЙНОЇ КОМПЕТЕНТНОСТІ МАЙБУТНІХ ОФІЦЕРІВ НАЦІОНАЛЬНОЇ ГВАРДІЇ УКРАЇНИ У ПРОЦЕСІ ФІЗИЧНОЇ ПІДГОТОВКИ

\title{
TECHNOLOGY OF FORMATION OF PROFESSIONAL COMPETENCE OF FUTURE NGU OFFICERS IN THE PROCESS OF PHYSICAL TRAINING
}

у статті на підставі теоретико-методологічного аналізу розглянуті елементи педагогічної технології. Завдання, що стоїть перед нами, має набагато ширше значення як результат свідомого сприйняття мети, як передумова реалізації мети на практиці. У прочесі вирішення педагогічного завдання у майбутніх офріцерів розвивається особистісно-психологічне утворення у структурі профресійної свідомості у формі знань, умінь і профресійно значущих якостей. Вирішення педагогічного завдання відбувається індивідуально. Навчальні заняття мають властивість універсального навчального впливу. Щоб курсант ефективно виконав поставлені завдання, необхідно їх ретельно підібрати за рівнем складності, рівнем фрізичного та розумового розвитку.

Проведений аналіз і дослідження психолого-педагогічної літератури свідчить про те, що в розробці технології формування профресійної компетентності у процесі фрізичної підготовки майбутнього офрічера НГУ дочільно визначити такі структурні елементи: мету, педагогічні завдання, компоненти, зміст, соорми, методи, етапи, результат. На основі аналізу сучасних підходів до розуміння сутності педагогічних технологій нами теоретично обгрунтовано і розроблено технологію формування профресійних умінь у майбутніх офріцерів НГУ у прочесі фрізичної підготовки.

Педагогічна технологія представлена такими етапами, як: теоретичне обгрунтування, розроблення технологічних процедур, застосування методики проведення занять, обгрунтування структурних компонентів, критеріїв і показників орормування професійних умінь, визначення психолого-педагогічних умов реалізації технології, результативність.

Під час проектування технології фрормування професійної компетентності майбутніх офріцерів НГУ у прочесі фрізичної підготовки ми дотримувалися також низки вимог: урахування мети фрормування професійних умінь, суспільних і особистих потреб, фрахових знань і навичок, особливості контролю, оцінювання результативності, ефективності технології.

Ключові слова: технологія, фрізична підготовка, майбутні офріцери, професійна компетентність, НГУ.
In the article on the basis of theoretical and methodological analysis the elements of pedagogical technology are considered, the task before us has much wider value as a result of conscious perception of the purpose, as a precondition of realization of the purpose in practice. In the process of solving the pedagogical task, future officers have a personal and psychological education in the structure of professional consciousness in the form of knowledge, skills and professionally significant qualities. The solution of the pedagogical task is individual. Lessons are a characteristic of universal educational influence. That a student executed the put tasks effectively, it is necessary them it is enough carefully to pick up after the level of complication, level of physical and mental development.

The analysis and research of psychological and pedagogical literature shows that in the development of technology for the formation of professional competence in the process of physical training of future officers of NGU it is advisable to identify the following structural elements: purpose, pedagogical tasks, components, content, forms, methods, stages, results. Based on the analysis of modern approaches to understanding the essence of pedagogical technologies, we have theoretically substantiated and developed the technology of forming professional skills of future NGU officers in the process of physical training.

Pedagogical technology is represented by the following stages: theoretical substantiation, development of technological procedures, application of teaching methods, substantiation of structural components, criteria and indicators of professional skills formation, determination of psychological and pedagogical conditions of technology implementation, effectiveness.

When designing the technology of formation of professional competence of future NGU officers in the process of physical training, we also followed a number of requirements: taking into account the purpose of professional skills, social and personal needs, professional knowledge and skills, control features, performance evaluation, technology efficiency.

Key words: technology, physical training, future officers, professional competence, NGU.
Постановка проблеми у загальному вигляді. Потреба фрормування профресійної компетентності майбутніх офріцерів НГУ у процесі фрізичної підготовки зумовлена рядом причин, направлених на фрормування у курсантів підвищення всебічної фрізичної підготовленості та вдосконалення фрізичних якостей, орормування професійно-прикладних навичок із пересування по пересіченій місцевості, подолання перешкод, рукопашного бою, військово-прикладного плавання та метання гранат, забезпечення високої професійної працездат- ності, підвищення стійкості організму до впливу несприятливих фракторів службово-бойової діяльності та навколишнього середовища [1, с. 7].

Це пояснюється низьким рівнем фрізичної підготовленості абітурієнтів і курсантів. Деякі дисципліни професійної спрямованості майбутніх офріцерів містять у собі елементи фрізичної підготовки: піші марші та марш-кидки, метання гранат, подолання перешкод на тактичній чи вогневій підготовці. Але цього не достатньо для сучасного офріцера. Дослідження показують, що близько 
75\% людей, які вступають на службу чи навчання до лав НГУ, не мотивовані до занять спортом і фрізичною культурою, хоча вони відносно фрізично розвинені та відповідають вимогам кандидатів на вступ.

Серед причин низького фрізичного розвитку науковці виділяють: необізнаність особливостей свого розвитку, недотримання навичок здорового способу життя, відсутність систематичних занять фрізичною культурою в сімейному, дошкільному та шкільному вихованні. Значне занепокоєння викликають несформованість мотивації на тривале та здорове життя, нерозвинена потреба у веденні здорового способу життя, відсутність знань, мотивації, переконань протидіяти руйнуючій поведінці, що призводить до втрати здоров'я. Варто зазначити, що у військовій педагогіці слабко розвинений зміст базових знань із фрізичної культури та здорового способу життя військових.

Одним зі шляхів вирішення цієї проблеми ми вважаємо фрізичну підготовку з метою формування професійної компетентності майбутніх офріцерів.

Проведене нами теоретичне дослідження проблеми формування професійної компетентності у процесі фрізичної підготовки довело необхідність розробки в педагогічній науці та впровадження результатів наукового пошуку в навчальний процес вищої школи.

Важливим засобом організації та вдосконалення процесу фрормування професійної компетентності у процесі фрізичної підготовки є розробка технології її формування.

Аналіз останніх досліджень і публікацій. Аналіз психолого-педагогічної літератури та наукових досліджень (І. Прокопенко, В. Гриньова, В. Лозова, Ю. Бойчук та ін.) свідчить, що у визначенні поняття «педагогічна технологія» вчені виходять із сутності терміна «технологія», цим терміном позначається сукупність знань про засоби та інструментарій проведення будь-яких процесів, а також процеси, за яких відбувається якісна зміна об'єкта дослідження.

Історично поняття «технологія» (грец. techne мистецтво, майстерність і logos - слово, вчення) у значенні науки про майстерність виникло у зв'язку з технічним прогресом. Американський вчений і педагог Дж. Саллі в 1886 р. використав термін «технологія» стосовно навчального процесу. Широке використання та розробку педагогічних технологій пов'язують із незадовільним станом традиційних форм і методів навчання, що не задовольняють сучасні вимоги системи освіти.

ЮНЕСКО використовує визначення, де, крім засобів інструментарію, запропоновано проектування, впровадження заходів і здійснення оцінки есрективності запропонованої технології [2, с. 29].

А. Нисимчук, О. Падалка, А. Шпак стверджують, що педагогічна технологія, як і кожна наука, у своєму розвитку послідовно проходить етапи: почат- ковий, класифікаційний, частково-системний, цілісно-системний. На їхню думку, сучасна теорія педагогічних технологій на початку XXI ст. перебуває на частково-системному етапі розвитку [3].

М. Лєвіна вважає, що «педагогічна технологія»це сукупність психолого-педагогічних установок, які визначають спеціальний набір і компоновку форм, методів та засобів і прийомів навчання, що становить організаційно-методичний інструментарій педагогічного процесу.

М. Кларін також дотримується трактування, поданого ЮНЕСКО, але засоби забезпечення певних процесів поділяє на людські, інструментальні та методологічні.

В. Монахов вважає, що педагогічна технологія - це продумана у всіх деталях модель спільної педагогічної діяльності із проектування, організації та проведення навчального процесу з безумовним забезпеченням комфортних умов для учнів і вчителя.

Н. Щурков подає більш стисле визначення педагогічної технології та доводить, що технологія має містити методи стимулювання й активізації діяльності людини.

Нам підходить трактування М. Махмутова: «Технологію можна представити як більш-менш жорстко запрограмований (алгоритмізований) процес взаємодії викладача з учнями, який гарантує досягнення поставленої мети». У цьому визначенні педагогічної технології увага привертається до структури взаємодії викладача й учня, цим визначаються способи впливу на учнів і результати цього впливу. Без педагогічно розвиненого мислення, без урахування багатьох фракторів педагогічного процесу, вікових, антропометричних та індивідуальних особливостей жодна технологія не виконає свого призначення. Перш ніж використовувати будь-яку технологію, потрібно вивчити усі їі особливості, з'ясувати, на що вона направлена, коли застосовується, яким педагогічним концепціям відповідає, які завдання вирішує.

Проаналізувавши визначення поняття «педагогічної технології», робимо висновок, що в освітньому середовищі термін трактується як складова частина педагогічної науки, яка містить мету, методи та проектування педагогічних процесів; здійснення педагогічного процесу на основі розробленої мети, змісту, методів і засобів досягнення результатів; спосіб реалізації педагогічного процесу. Технологія фрормування профресійної компетентності у процесі фрізичної підготовки майбутнього офріцера, що є функціональною педагогічною системою, включає всі етапи, починаючи від постановки мети, визначення завдань і проектування подальших дій до її реалізації.

Першим кроком у розробці педагогічної технології $€$ ії мета. Спираючись на дані наукових досліджень низки вчених (М. Кларін, Ю. Трофрімов, 
П. Гусак та ін.), розуміємо, що від чіткості постановки мети залежить подальший процес. Під час розробки технології фрормування профресійної компетентності майбутніх офріцерів у процесі фрізичної підготовки визначення мети передбачає обґрунтування й інших її компонентів.

С. Сисоєва вважає, що педагогічна технологія повинна відповідати таким основним методологічним вимогам (критеріям технологічності), як-то: концептуальність (кожній педагогічній технології має бути притаманна опора на певну наукову концепцію, що включає фрілософське, психологічне, дидактичне і соціально-педагогічне обґрунтування досягнення освітніх цілей); системність (педагогічна технологія повинна мати всі ознаки системи: логіку процесу, взаємозв'язок усіх його частин, цілісність); керованість (припускає можливість правління навчальним процесом, поетапну його діагностику, варіювання засобами і методами 3 метою корекції результатів); ефективність (сучасні педагогічні технології існують за конкурентних умов і повинні бути ефективними за результатами й оптимальними витратами, гарантувати досягнення визначеного стандарту навчання та виховання); відтворюваність (мається на увазі можливість застосування (повторення, відтворення) педагогічної технології в інших однотипних освітніх установах, іншими суб'єктами.

Розробляючи технологію навчання для системи освіти, необхідно враховувати зміст майбутньої діяльності вимоги до професійно важливих якостей офріцера.

П. Гусак виділяє такі дидактичні принципи: інтеграції, орієнтованості на досягнення досвіду, творчої спрямованості.

Серед загальнодидактичних принципів, на яких базуються педагогічні технології, особливо важливими для технології фрормування професійної компетентності майбутніх офріцерів НГУ у процесі фрізичної підготовки є: системність, неперервність, науковість, орієнтування на інновації та фрормування творчого мислення.

Принцип системності тісно пов'язаний із принципом науковості та передбачає наявність у курсанта сукупності знань, що адекватні зв'язкам між знаннями всередині наукової теорії.

Принцип неперервності передбачає прогностичний характер навчання, що забезпечує фрормування профресійної компетентності у процесі фрізичної підготовки під час РФЗ, на заняттях, індивідуальних тренувань, тренувань за умов виконання службово-бойових завдань, спортивномасової роботи курсантів.

Принцип науковості передбачає відповідність навчальних і наукових знань, застосування методів наукового пізнання.

Відповідно до принципу орієнтування на інновації навчальний процес у ЗВО повинен бути спря- мований на впровадження науково обґрунтованих та експериментально перевірених новітніх педагогічних технологій.

Принцип фрормування творчого мислення спрямовує орієнтування курсантів у потоці нових наукових фрактів і теоретичної інформації на безперервне нарощування рівня відповідних знань та адаптацію до постійних змін науки та технологій. Крім цього, принцип забезпечує процеси самоорганізації та самореалізації майбутнього офіцера.

М. Кларін відносить до інноваційних моделей навчання у своїх роботах:

- спрямування мети освіти на розвиток і саморозвиток особистості, яка має змогу вільно орієнтуватися в новій інноваційній і науковій діяльності;

- оновлення змісту навчання, що дає змогу виключення із запропонованого змісту описового матеріалу та інтегрування змісту суміжних дисциплін як в аудиторній, так і позааудиторній роботі, на основі створення курсів, фракультативів та ін.;

- надання переваги процесу учіння над процесом подання викладачем нового матеріалу, що передбачає посилення процесів самоосвіти та самовдосконалення курсантів під керівництвом викладача. А це потребує перенесення акцентів на самостійну роботу, щоб майбутні офріцери могли здійснювати пошуково-дослідницьку, експериментальну роботу за індивідуальними можливостями;

- відповідне матеріально-технічне та навчально-методичне забезпечення навчального процесу.

Виділення не вирішених раніше частин загальної проблеми. Наведені та розглянуті елементи педагогічної технології спонукають до пошуку та висвітлення інших складників. Логічно, що під час побудови педагогічної технології поряд із метою та концептуальними основами стоять завдання, які між собою тісно пов'язані.

Мета статті. У цій роботі поставлене перед нами завдання має набагато ширше значення як результат свідомого сприйняття мети, як передумова реалізації мети на практиці.

Виклад основного матеріалу. До навчального завдання висуваються такі вимоги: створювати потрібно не окреме завдання, а групу завдань; під час створення системи завдань потрібно прагнути забезпечення досягнення усіх цілей технології; завдання повинні забезпечувати засвоєння системи засобів необхідної та достатньої вдалого здійснення навчальної діяльності; завдання повинно конструюватися так, щоб відповідні засоби діяльності, засвоєння яких передбачається у процесі вирішення, виступали прямим продуктом навчання [4, с. 44].

У процесі вирішення педагогічного завдання у майбутніх офріцерів має сформуватися особистісно-психологічне утворення у структурі профресійної свідомості у фрормі знань, умінь і профе- 


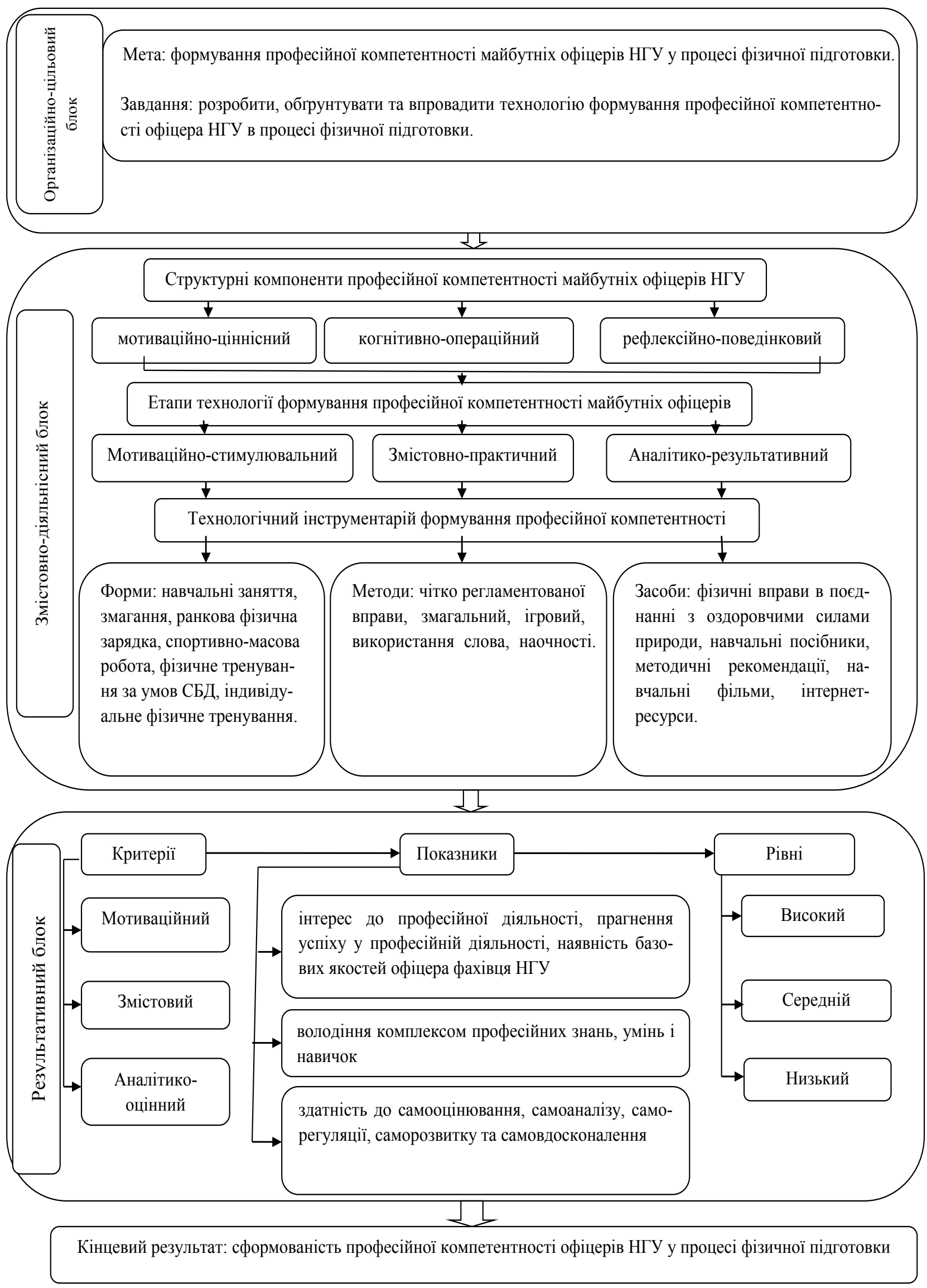

Рис. 1 
сійно значущих якостей. Вирішення педагогічного завдання відбувається індивідуально. Навчальні заняття мають властивість універсального навчального впливу. Щоб курсант ефективно виконав поставлені завдання, необхідно їх ретельно підібрати за рівнем складності, рівнем фізичного та розумового розвитку.

Проведений аналіз психолого-педагогічної літератури свідчить про те, що в розробці технології фрормування професійної компетентності у процесі фрізичної підготовки майбутнього офріцера НГУ доцільно визначити такі структурні елементи: мету, педагогічні завдання, компоненти, зміст, форми, методи, етапи, результат.

Організаційно-цільовий блок моделі фрормування професійної компетентності у майбутніх офріцерів НГУ містить цільову складову частину.

Цільова складова частина визначає мету і завдання фрормування професійної компетентності у майбутніх офріцерів НГУ, є підставою для проектування очікуваних результатів. Як мету, як ідеальний прообраз результату функціонування технології ми визначаємо формування профресійних умінь у майбутніх офріцерів. Для ії досягнення необхідно вирішити завдання, що передбачає дії для отримання проміжних результатів.

У змістовно-діяльнісному блоці, з огляду на зазначену структуру формування професійної компетентності у процесі фрізичної підготовки, метою $\epsilon$ формування мотиваційно-ціннісного, когнітивно-операційного і рефрлексивно-поведінкового компонентів. Виділяємо такі етапи технології формування професійної компетентності у процесі фрізичної підготовки: мотиваційно-стимулювальний, змістовно-практичний, аналітикорезультативний. Мотиваційно-стимулювальний етап спрямований на стимулювання позитивної мотивації до набуття професійної компетентності, що стане можливим через розвиток у майбутніх офріцерів відповідальності за своє здоров'я, фрізичних якостей і профессійної працездатності для здійснення інтенсивної розумової діяльності через розвиток і вдосконалення аналізаторів, таких як зорові, слухові, тактильні, вестибулярні, фрормування спеціально спрямованих рухових умінь і навичок, підвищення стійкості організму до несприятливих фракторів, пов'язаних зі службово-бойовою діяльністю.

Змістовно-практичний етап передбачає розвиток позиції особистості як суб'єкта діяльності, отримання досвіду, заохочення в колективі індивідуальних досягнень курсантів, що передбачає використання різних форм фрізичної підготовки.

На аналітико-результативному етапі передбачається проведення аналізу й оцінка отриманих результатів щодо ефрективності формування профресійної компетентності у процесі фрізичної підготовки з метою ії корегування.
При визначенні технологічного інструментарію розробленої технології $€$ тандем із традиційних та інноваційних методів, взаємодія яких сприятиме есрективному вирішенню завдань щодо формування профресійної компетентності майбутніх офріцерів у процесі фрізичної підготовки.

Під час дослідження виявлено такі методи фрормування профеесійної компетентності у процесі фрізичної підготовки: чітко регламентованої вправи, змагальний, ігровий, використання слова, наочності.

До форм фрормування профресійної компетентності у процесі фрізичної підготовки відносимо: ранкову фрізичну зарядку, навчальні заняття, спортивно-масову роботу, фізичне тренування за умов СБД, індивідуальне фрізичне тренування.

Фізична підготовка $€$ основним предметом бойової та спеціальної підготовки майбутніх офріцерів НГУ та має забезпечувати необхідний рівень їхньої фрізичної готовності до виконання завдань за призначенням [1, с. 7].

Науково-педагогічним працівникам необхідно оптимізувати фрізичні навантаженням 3 урахуванням індивідуальних особливостей курсантів, використовувати сучасні методики, що дозволить досягти високих результатів. Стосовно правил проведення навчальних занять, то застосовують поступове збільшення навантаження, основне тренувальне завдання та на закінчення - зниження навантаження. Фізіологічна крива навантаження поступово підіймається, після чого деякий час перебуває на високому рівні та після цього різко знижується, вона притаманна для усіх тренувань у будь-якій фрормі.

Структура занять із фрізичної підготовки визначається зміною працездатності курсантів. У першій частині заняття рівень працездатності зростає, потім перебуває на високому рівні та до кінця заняття знижується.

Беручи до уваги еволюційно ссрормований характер стану організму у процесі рухової діяльності та силу біологічних закономірностей, що проявляється на занятті, незалежно від змісту тренування, виділяють підготовчу, основну та заключну частину заняття.

До підготовчої частини заняття включають початкову організацію курсантів - забезпечення порядку при підготовці до заняття, перевірку о/с, пояснення мети та змісту заняття. Головне місце в підготовчій частині заняття займає функціональна підготовка організму курсантів до основної діяльності. Цедосягаєтьсязавдякивправам, що непотребують тривалого часу на підготовку та виконання.

Основна частина заняття призначена для найбільш складних завдань заняття, забезпечення фрундаментальності фрізичної за допомогою навчання спортивної техніки і тактики, виховання вольових якостей, розвитку сили, швидкості, 
витривалості, спритності. Разом із використанням методів чітко регламентованої вправи в основній частині заняття для підвищення емоційного стану та інтенсивності прояву фрізичних якостей застосовують змагальний та ігровий метод.

У заключній частині заняття необхідно забезпечити поступове зниження фрункціональної активності організму. Прибирання місць занять, перешикування до закінчення заняття сприяють поступовому зниженню навантаження. Освітні задачі для заключної частини заняття: навчити поступово знижувати інтенсивність вправ, аналізувати виконану роботу. Для заключної частини заняття підбирають легко дозовані вправи: повільний біг, ходьбу, елементарні рухи.

Один із важливих елементів - це завдання на самостійну підготовку, адже навчальні заняття лише частина процесу фрізичного виховання. Недооцінене ставлення до самостійної роботи порушує зв'язок між заняттями під керівництвом викладача та іншими фрормами занять.

Навчальні заняття фрормують у курсантів настанову на фрізичне вдосконалення, потребу в регулярних заняттях фрізичним вправам і спортом та фрормують професійну компетентність для вдалого виконання службово-бойових завдань і функціональних обов'язків.

Методи чітко регламентованої вправи передбачає організацію та регулювання 3 повною регламентацією, яка складається з: чітко визначеної програми рухів; у можливому чіткому дозуванні навантаження та керування ії динамікою під час виконання, а також можливість нормування відпочинку та навантаження; у створенні зовнішніх умов які полегшують процес керування діями курсантів. Суть такої регламентації полягає в забезпеченні оптимальних умов для засвоєння нових рухових навичок, чітко направленої дії для розвитку фрізичних якостей і здібностей. Методи чітко регламентованої вправи мають велику кількість варіантів, використання яких залежить від змісту занять.

Ігровий метод у фрізичному вихованні характеризується такими ознаками, як: організація; різноманітність досягнення мети; самостійність дій курсантів і їхня ініціативність; підвищена емоційність і моделювання напружених міжособистісних відносин; можливість програмування дій та обмежені можливості точного дозування навантаження. Ігровий метод використовується у фрізичному вихованні здебільшого для комплексного вдосконалення рухової діяльності за ускладнених умов. Він дозволяє вдосконалювати такі якості, як: спритність, швидкість орієнтування, кмітливість, самостійність та ініціативність. У військовому колективі цей метод дієвий для виховання та зміцнення колективу, дисципліни, свідомості та інших якостей особистості.
Змагальний метод або змагання у процесі фрізичної підготовки використовують у різних фрормах (від елементарного до розгорнутого). Основна риса цього методу - зіставлення сил за умов боротьби за перемогу чи високе досягнення. Фактор суперництва у процесі змагань і їх організації (нагородження, заохочення) створюють емоційну та фрізіологічну атмосфреру, що підсилює вплив фрізичних вправ і може сприяти максимальному прояву фрункціональних можливостей організму [5, с. 87]. Функціональні зрушення за умов змагань більш значні, ніж під час не змагальних навантажень. Спортивні змагання виступають як засіб активації загальнофрізичної, спортивно-прикладної та психологічної підготовки майбутніх офріцерів.

Інтегративним показником якості й ефективності психофрізичної підготовки курсантів виступають спортивні результати. За умов проведення змагань курсанти більш повно демонструють фрізичні можливості та підготовленість. Тому контроль із фрізичної підготовки проводиться у змагальній обстановці.

Спортивні змагання можуть виступати як метод контролю ефективності навчального процесу.

Метод використання слова пов'язує практично всі сторони діяльності викладача у процесі фрізичної підготовки. За допомогою слів ставлять завдання, аналізують та оцінюють результати, повідомляють інформацію та знання, активізують сприйняття. Слово відіграє необхідну роль у самооцінці та саморегуляції курсантів. Залежно від функцій слова використовують різні методи застосування. Загально-педагогічні методи - бесіда, обговорення, дидактична розповідь та ін., - у фрізичній підготовці зазвичай виступають у більш лаконічній фрормі, цьому сприяє спеціальна спортивна термінологія. Під час проведення заняття використовуються словесні методи, які забезпечують високу щільність занять, органічно пов'язують слова з рухами. До них відносять: інструктаж; попутні пояснення; команди та вказівки; словесну оцінку; словесні взаємні пояснення; самообговорення, самонакази.

Методи забезпечення наочності у процесі фрізичної підготовки використовується як опора на свідчення усіх органів і відчуттів, завдяки яким досягається контакт із використанням рухових, зорових та інших аналізаторів. Забезпечуючи наочність, застосовують комплекс методів, заснованих на опосередкованому сприйнятті вправ, які вивчаються, їхніх окремих сторін, характеристик, умов виконання. Ці методи розподіляють на методи натуральної та опосередкованої демонстрації.

Ці всі методи навчання притаманні фрізичній підготовці курсантів, вони направлені на формування професійної компетентності майбутніх офріцерів НГУ, виховання сміливості, рішучості, впевненості у своїх силах, високого рівня фрізичної підготовленості для виконання службово-бойових завдань. 
Результативний блок визначає успішність функціонування технології формування професійної компетентності майбутнього офріцера НГУ у процесі фрізичної підготовки із визначенням критеріїв, показників і рівнів сорормованості професійної компетентності, результатом чого $€$ срормованість професійної компетентності майбутніх офріцерів НГУ у процесі фрізичної підготовки.

Висновки. Отже, запропонована технологія формування професійної компетентності у майбутніх офріцерів НГУ дає можливість вирішувати сукупність завдань для виховання всебічно і гармонійно розвиненої особистості з високим рівнем сорормованості профресійних умінь.

\section{БІБЛІОГРАФІЧНИЙ СПИСОК:}

1. Інструкція 3 організації фрізичної підготовки в Національній гвардії України / Лещеня С.В., Орленко
І.П., Мелешко А.О., Забродський С.С. ; під заг. ред. Мальцева О.Н. Київ, 2014. 140 с.

2. Klingsted G.L. Developing instructional modules for individualized instruction. Educational technology. 2008. № 11. P. 74.

3. Нісімчук А.С., Падалка О.С., Шпак О.Т. Сучасні педагогічні технології : навчальний посібник. Київ : Видавничий центр «Просвіта»; Пошуково-видавниче агентство «Книга Пам'яті України», 2000. 368 с.

4. Турчинов А.В. Формування здоров'язбережувальної компетентності майбутніх офіцерів Національної гвардії України у процесі професійної підготовки : дис. ... канд. пед. наук : 13.00.04. Хмельницький, 2017.

5. Матвеєва Л.П. Теорія та методика фрізичного виховання : навчальний посібник. Ч. 1: Загальні основи теорії та методики фрізичного виховання / під заг. ред. Л.П. Матвеева, А.Д. Новікова. Москва : Фізична культура та спорт, 1976. 304 с. 